\title{
Business Failure Prediction using Sherrod and Kida Models: Evidence from Banks Listed on Iraqi Stock Exchange (2011 - 2014)
}

\author{
Islam S. T. Babela and Renas I. Mohammed \\ Banking \& Financial Sciences, College of Administration and Economic, University of Zakho, Kurdistan Region, Iraq.
}

https://doi.org/10.26436/2016.4.2.404

\begin{abstract}
Nowadays business environment characterized by different types of risks and relatively high business uncertainty levels. This is because of the changes that have taken place by globalization and liberalization. To avoid these risks, it has been a very important matter for financial institutions to give much more attention to performance evaluation and use advanced tools for early detection of business failure. Therefore, in the financial literature, business failure prediction has been widely studied. From this standpoint, this paper attempts to investigate whether the banks listed on the Iraqi Stock Exchange (ISE) expose to business failure by using Sherrod and Kida models. The population of this paper is restricted to banks listed on the (ISE) from 2011 to 2014. Sixteen banks were selected from the total of twenty three. We entirely relied on secondary data which obtained from financial statements of the selected banks.

The study reveals that the exposure of selected banks to the risk of bankruptcy is very low based on Sherrod's Z-score model. In contrast, the selected banks have serious problems and their exposure to bankruptcy is very high according to Kida's Z-score model. The study also has concluded that the latter model is unreliable to be applied by banks listed on ISE as its results do not compatible with works of selected banks. The finding of the study can be useful for managers, stockholders, investors and concerned users to visualize the ability of banks' sustainability.
\end{abstract}

Key words: Business failure prediction, Sherrod, Kida, Z score model, Iraq.

\section{Introduction}

I

$t$ is argued that the economic growth of every country to be sustainable, it is very important to have a control over the number of failure firms (Uchenna and Okelue, 2012:86). This means that an evaluation and predicting business failure might help firms for taking the necessary precautions and actions to avert a possible financial failure. For this reason, over the last few decades, business failure has been considered one of the hottest topics that dominated the study of researchers and a preoccupation of practitioners in the field of corporate finance (Arkan, 2015: 233). To support this, a variety of models have been proposed and tested empirically in an attempt to predict business failure. For example, Beaver (1966), Altman (1968), Deakin (1972), Kida (1980), Ohlson (1980), Taffler (1983), Sherrod (1987) and Shirata (1998) (Gharaibeh et al., 2013: 313). Practitioners use business failure prediction models to evaluate firms that are likely to face a potential financial distress. These models are used in financial institutions in order to evaluate the risk of loan default; they are used by investors to assess current or future investment decision, and creditors, to decide whether to deal with a certain firm. Therefore, business failure is the main concern to the stakeholders of any corporation which include management, employees, investors, creditors, government etc. as it may generate huge losses and high costs to the economy and the society as a whole (Ahn et al., 2000: 66). In general, research articles confirm that the business failure prediction is perhaps one of the main substantial business decision-making problems, as the decision that made could have an effect on the whole life span of a firm (Tam and Kiang, 1992: cited in Mohammed and Soon, 2012:1).

The purpose of this study is: i) to evaluate the situation of banks listed on the ISE whether they experience the risk of financial failure by using Kida and Sherrod models. ii) To determine the differences (if any) between these two models when they applied to the data of the banks listed on the ISE.

In several ways this study has a contribution to the literature on business failure. Firstly, the majority of earlier studies concentrated on developed countries to apply business failure prediction models. However, this study focuses on Iraqi economy as a developing country for providing empirical evidence. Secondly, previous published studies in Iraq are limited in terms of the model used and the size of sample. For example the study of (Alhamdani and 
Alqattan, 2013) concentrated only on Sherrod as a model of business failure prediction and one manufacture as a sample of the study. Similarly, the study of (Aziz, 2014) has used Kida model and focused on ten banks that listed on ISE. On the other hand, this study focuses on recent set of data. Furthermore, it attempts to predict financial failure of (16) banks listed on the ISE by using both Kida and Sherrod Models.

The reminder of this paper is organized as follow: the next sections discuss the methodological issues of the paper. Section two sheds light on the empirical review of related literature and the techniques used to predict bank failure. Section three is devoted to analysis of results and the final section summarizes key findings and provides conclusions.

\section{Section One: Methodology}

1. Statement of the problem: Using ratios make conflicting predictions about a given business and they do not tell the whole story behind the firm's prospects. Thus, they are unreliable to predict business failure as their results analyse and interpret business operations inaccurately (Gepp and Kumar, 2012:5; Pike and Neale, 2009:337). Accordingly, this study attempts to answer the following questions:

- To what extend the banks listed on the ISE expose to bankruptcy risk by using Sherrod and Kida Z-score models?

- To what extend Kida's Z-score model differ from Sherrod's Z-score model for predicting business failure?

2. Significance of the study: Predicting business failure is useful to various parties. The results of the current study could help management, shareholders and investors. In addition, the application of these models might be an effective early warning tool to predict bank failure even before it occurs.

3. Objective of the study: The objective of this study is to predict the financial distress of banks listed on the ISE. This study also aims to identify the differences between these two models (if any).

4. Hypotheses of the study: To achieve the objectives of the study, the following hypotheses have been formulated:

H1: There is a possible exposure of financial failure of banks listed on the ISE.

H2: There are no significant differences in the accuracy level of prediction between Sherrod's Z-score model and Kida's Z-score model when both applied to banks listed on the ISE.
5. Data Analysis Method: This study has adopted two models to achieve its objectives, as shown below:

\subsection{Sherrod Model:}

$Z=17 X_{1}+9 X_{2}+3.5 X_{3}+20 X_{4}+1.2 X_{5}+0.10 X_{6}$

Where:

$\mathrm{X}_{1}=$ Working capital / total assets.

$\mathrm{X}_{2}=$ cash assets / total assets.

$\mathrm{X}_{3}=$ total shareholders' equity / total assets.

$\mathrm{X}_{4}=$ earnings before interest and taxes / total assets.

$\mathrm{X}_{5}=$ total assets / total liabilities.

$\mathrm{X}_{6}=$ total shareholders' equity / tangible fixed assets.

\subsection{Kida Model:}

\section{$\mathrm{Z}=-1.042 \mathrm{X} 1-0.427 \mathrm{X} 2-0.461 \mathrm{X3}-0.463 \mathrm{X} 4+$ $0.271 X 5$}

Where:

$\mathrm{X}_{1}=$ net income / total assets.

$\mathrm{X}_{2}=$ total shareholders' equity / total debt.

$\mathrm{X}_{3}=$ quick assets / current liabilities.

$\mathrm{X}_{4}=$ sales (revenue) / total assets.

$\mathrm{X}_{5}=$ cash $/$ total assets.

6. Source of data: Due to the nature of this study, we entirely relied on secondary data which are publicly available in the financial statements of the banks. The data were obtained from the ISE website namely http://www.isx-iq.net/

7. Population and Sample selection: The study is restricted to banks listed on ISE. A nonprobability sampling technique has been employed for a sample size of 16 banks (see table 1.1) from the total of 23 banks listed on (ISE) during the period 2011 to 2014 . To be selected, Islamic banks were excluded as they do not deal with loans and their banking operations differ from conventional banks. Furthermore, banks that do not have financial statements from 2011 to 2014 were excluded.

Table (1): Study sample

\begin{tabular}{clc}
\hline $\mathrm{n}$ & \multicolumn{1}{c}{ Banks } & Establishing date \\
\hline 1 & $\begin{array}{l}\text { Al-Mansour bank for } \\
\text { investment }\end{array}$ & 2005 \\
\hline 2 & Ashur International Bank & 2005 \\
\hline 3 & Babylon bank & 1999 \\
\hline 4 & Bank of Baghdad & 1992 \\
\hline 5 & Commercial bank of Iraq & 1992 \\
\hline 6 & Credit bank of Iraq & 1998 \\
\hline 7 & $\begin{array}{l}\text { Dar Es salam investment } \\
\text { bank }\end{array}$ & 1998 \\
\hline 8 & Gulf commercial bank & 1999 \\
\hline 9 & Investment bank of Iraq & 1993 \\
\hline 10 & $\begin{array}{l}\text { Iraqi middle east } \\
\text { investment bank }\end{array}$ & 1993 \\
\hline 11 & $\begin{array}{l}\text { Mosul bank for finance } \\
\text { and investment }\end{array}$ & 2001 \\
\hline
\end{tabular}




\begin{tabular}{lll}
\hline 12 & National bank of Iraq & 1995 \\
\hline 13 & $\begin{array}{l}\text { North bank for finance } \\
\text { and investment }\end{array}$ & 2003 \\
\hline 14 & Sumer Commercial bank & 1999 \\
\hline 15 & Union bank of Iraq & 2002 \\
\hline 16 & $\begin{array}{l}\text { United bank for } \\
\text { investment }\end{array}$ & 1994 \\
\hline
\end{tabular}

Source: Authors

\section{Section Two: Literature review}

\section{Default Prediction Studies Utilizing}

\section{Accounting Information:}

The early attempt to predict bankruptcy was Fitzpatrick (1932). Fitzpatrick used financial ratios for comparing between successful and failure business. Since, the study on business failure has been recognized widely by the researchers. To predict business failure, (Beavers, 1966) was the first researcher who used usefulness of financial ratios to employ Univariate Discriminant Analysis (UDA). The consideration of this model is to minimize misclassification costs by calculating accounting ratios individually and a cut off point for each ratio and the accuracy prediction ranges between 50\% to above $90 \%$ (Okay, 2015: 5).

In this context, many others have since proposed the usefulness of accounting data. According to Poston, K. M., et al., (1994: 43) in the forms of methodological refinements, the most notable contributions are (e.g., Altman, 1968; Deaken, 1972, 1977; Altman, Haldeman and Narayanan, 1977; Ohlson, 1980; Casey and Bartczak, 1985; and Gentry et al., 1985). However, the classification of sample firms into failed or non-failed was a major weakness of these works. This is because, any firm before it reaches the final stage of collapse, it may be able to remedy its weaknesses positions, and this artificial dichotomization does not explicitly recognizing that.

Over the years, to predict a business failure, researchers used a variety of methods normally constructed using either internal or external bank data (Tatum, 2011:3). These modules (techniques) were; Univariate Analysis (UA), Discriminant Analysis (DA), Logit and Probit Analysis (LA), Human Information Processing (HIP), Artificial Neural Networks (ANN), Sequential Procedures, Decision Tree (DT), and Other Standard Multivariate Techniques such as Principal Component Analysis, Factor Analysis and Cluster Analysis (Gepp \& Kumar, 2012: 2).

The Univariate Discriminant Analysis model has later been criticized in spite of its good prediction. This is because applying Univariate model with the same company using different ratios may produce conflicting results (Okay, 2015: 5). Thus, according to Edmister, (1972:1491), to capture all the aspects and variables of failure, the univariate approach might not be sufficient as the situation of a company in a financial environment does not rely only on one factor. Consequently, Altman Z-score has been introduced as a first Multivariate Discriminant Approach (MDA) in 1968 by Altman, after he improves the Univariate approach of Beaver 1966 (Okay, 2015: 6).

\section{The Definition of Business Failure:}

There is no a uniform definition of business failure. In the literature, there are a wide range of definitions depending on the researchers' point of view. Thus, business failure prediction has many aliases, such as, financial distress prediction, bankruptcy prediction and firm failure prediction. Hence, all the given aliases attempt to predict the failure before it actually happens. Statistically business failure prediction relies on financial ratios from financial statements to predict the failure or success of a business (Gepp \& Kumar, 2012: 2).

Altman and Hotckiss (2005) define failure "by economic criteria, means that the realized rate of return on invested capital, with allowances for risk consideration, is significantly and continually lower than prevailing rates on similar investments Somewhat different economic criteria have also been utilized, including insufficient revenues to cover costs and where average return on investment is continually below the firm's cost of capital. These economic situations make no statements about the existence or discontinuance of the entity." Furthermore, failure, by financial criteria, can be defined as "insufficient cash flow to satisfy current obligations. These obligations might include outstanding debts to suppliers and employees, incurred losses from ongoing legal processes, default in repayment of principal and interests" (Aktan, 2011:20).

As a general approach financial failure means the inability to meet current liabilities as they come due because of insufficient liquidity.

\section{Cause of Failure:}

Business failure occurs when company's returns are negative or low and this, in turn, is probably lead to a serious financial failure unless is remedied (Gitman and Zutter, 2012: 737). In 
the same context, Altman (1986) indicated that there is a strong possibility that companies fail if they are not making profit, more relined on loans and they suffer from cash flow difficulties (Keener, 2013:375).

It has been suggested that failures can be predicted either by observing the performance indicator or by implementing and analyzing the strategic plan. A list of causes contributing to the failure has been developed almost in all the studies on the causes of failure. Thus, some of the useful insights into the causes of failures have been provided (table 2 ).

Table 2: Set of main factors affecting the performance of a business entity

\begin{tabular}{cc}
\hline Internal Factor & External Factor \\
\hline Poor management (Quality Management). & Social environment. \\
\hline Dissonance to the environmental developments. & Industrial Environment. \\
\hline Insufficient communication. & Economic Environment. \\
\hline Unbalanced growth. & Natural Environmental. \\
\hline Failure in the main projects. & Technological Environment. \\
\hline
\end{tabular}

Source: Aktan, S. (2011). Early Warning System for Bankruptcy: Bankruptcy Prediction. (Doctoral thesis, des Karlsruher Instituts für Technologie (KIT), Germany). Retrieved 30 June 2016, from http://d-nb.info/1019790032/34

\section{Business Failure Prediction Models:}

Since its beginnings in the 1960's, many different techniques have been applied to predict business failure. The business failure prediction has been arguably started earlier. However, the first modern statistical model for business failure prediction was published before that (Gepp \& Kumar, 2012: 4). One criticism of much of the literature on these models is that, they are questionable in terms of suitability and performance, as the data used were from developed economies. In addition, these models were developed during the late 60 's. Since then the business environment has seen a lot of changes in many aspects (Boritz et al., 2007: 144). However, several studies have revealed that these models were able to predict occurrence of financial failure in a large percent in many situations. In this paper the Multivariate Discriminant Approach (MDA) is been reviewed and referenced using Kida's Z-score model and
Sherrod's Z-score model. As well as the following models are ones of the most modern models in predicting financial failure (Arkan, 2015: 240).

4.1 Sherrod Model: Sherrod model is considered one of the advanced models for detecting the phenomenon of financial failure. Six independent financial indicators were depended on by this model, as well as the relative weights of the discrimination function coefficients given for these variables (Arkan, 2015: 240). According to (Abu Orabi, 2014:33), the discriminant function developed by Sherrod is as follow:

$$
\begin{aligned}
& Z=17 X_{1}+9 X_{2}+3.5 X_{3}+20 X_{4}+1.2 X_{5}+ \\
& 0.10 X_{6}
\end{aligned}
$$

To measure the ability to continue according to the degree of risk, business firms have been given five categories as follows:

Table 3: Categories according to the degree of risk and to measure the ability to continue

\begin{tabular}{ccc}
\hline Category & Risk degree & $\mathrm{Z}$ score \\
\hline 1st & Company is not exposed to the risk of bankruptcy & $\mathrm{Z}>25$ \\
\hline 2nd & Little likelihood of exposure to the risk of bankruptcy & $25 \geq Z>20$ \\
\hline 3rd & Difficult to predict the risk of bankruptcy & $20 \geq Z>5$ \\
\hline 4th & The Company is exposed significantly to the risk of bankruptcy & $5 \geq Z>-5$ \\
\hline 5th & The Company is exposed to the risk of bankruptcy & $\mathrm{Z} \leq 5-$ \\
\hline
\end{tabular}

Source: Abu Orabi, M.M. (2014). Empirical Tests on Financial Failure Prediction Models. Interdisciplinary journal of contemporary research in business, 5(9), 29-43. 
The above model shows that companies considered as a good sign for being successful who have a Z-score of > 25. However, companies may not be able to continue due to potential serious problems that have a $\mathrm{Z}$-score 5 $\geq Z>-5$ and $Z \leq 5-$. Hence, the financial position of the business firm is strong and it has a very good chance to continue with a degree of low risk if the Z-score increases. However, the financial position of the business firm is facing the difficulties to continue with a high degree of risk if the Z-score decreases.

4.2 Kida model: Kida's model relied on five separate financial indicators to predict financial failure (Alkhatib and Al Bozur, 2011: 209). According to (Kida, 1980: 513), the discriminant function developed by Kida is as follow:

\section{$\mathrm{Z}=-\mathbf{1 . 0 4 2} \mathrm{X}_{1}-0.427 \mathrm{X}_{2}-0.461 \mathrm{X}_{3}-0.463 \mathrm{X}_{4}+$ $0.271 X_{5}$}

A negative Z-score implies a problem firm, where as a positive Z-score implies a nonproblem firm.

Section Three: Data presentation, analysis and interpretation

To achieve the objectives of the study, multi discriminant analysis model (Z-score) of Sherrod and Kida has been employed to 16 banks listed on (ISE) to predict their financial position during the period 2011 to 2014.

The outcomes of Z-score for each bank were extracted through excel spreadsheets and only two digits have been taken after decimal point. The results of data analysis have been computed as follows:

\section{Al-Mansour bank for investment:}

Table (4): The outcomes of Sherrod and Kida models

\begin{tabular}{ccccccc|ccccccc}
\hline modey & \multicolumn{7}{c|}{ Sherrod Model } & \multicolumn{5}{c}{ Kida Model } \\
\cline { 2 - 13 } years & $\mathrm{X}_{1}$ & $\mathrm{X}_{2}$ & $\mathrm{X}_{3}$ & $\mathrm{X}_{4}$ & $\mathrm{X}_{5}$ & $\mathrm{X}_{6}$ & $\begin{array}{c}\mathrm{Z} \text { - } \\
\text { score }\end{array}$ & $\mathrm{X}_{1}$ & $\mathrm{X}_{2}$ & $\mathrm{X}_{3}$ & $\mathrm{X}_{4}$ & $\mathrm{X}_{5}$ & $\begin{array}{c}\mathrm{Z} \\
\text { score }\end{array}$ \\
\hline 2011 & 6.40 & 8.77 & 1.41 & 0.70 & 2.01 & 1.55 & $\mathbf{2 0 . 8 4}$ & -0.03 & 0.29 & 0.75 & 0.03 & 0.10 & $\mathbf{- 1 . 0 1}$ \\
\hline 2012 & 10.07 & 8.80 & 2.15 & 0.68 & 3.11 & 2.81 & $\mathbf{2 7 . 6 3}$ & -0.03 & 0.68 & 1.17 & 0.02 & 0.06 & $\mathbf{- 1 . 8 4}$ \\
\hline 2013 & 5.82 & 8.88 & 1.24 & 0.76 & 1.86 & 2.76 & $\mathbf{2 1 . 3 2}$ & -0.03 & 0.23 & 0.71 & 0.02 & 0.07 & $\mathbf{- 0 . 9 2}$ \\
\hline 2014 & 5.20 & 8.88 & 1.12 & 0.47 & 1.76 & 2.43 & $\mathbf{1 9 . 8 6}$ & -0.02 & 0.20 & 0.67 & 0.02 & 0.09 & $\mathbf{- 0 . 8 2}$ \\
\hline
\end{tabular}

Source: Authors

As can be seen from the table (4), the Z-score of Sherrod's models has achieved the highest number in 2012 which reveals a good sign for being successful because the Z-score is bigger than 25. While, in 2011 and 2013 the results were 20.84 and 21.32 respectively, which means that the probability of failure is very low.
However, the result of 2014 shows that the prediction of bankruptcy is difficult as the Zscore is less than 20. In contrast, the outcome of Kida's Z-score interpret that the financial position of the bank is weak and there is a chance to face the risk of failure because the results are negative.

\section{Ashur International Bank:}

Table (5): The outcomes of Sherrod and Kida models

\begin{tabular}{|c|c|c|c|c|c|c|c|c|c|c|c|c|c|}
\hline moc & \multicolumn{7}{|c|}{ Sherrod Model } & \multicolumn{6}{|c|}{ Kida Model } \\
\hline & $\mathrm{X}_{1}$ & $\mathrm{X}_{2}$ & $\mathrm{X}_{3}$ & $\mathrm{X}_{4}$ & $\mathrm{X}_{5}$ & $\mathrm{X}_{6}$ & $\begin{array}{l}\text { Z- } \\
\text { score }\end{array}$ & $\mathrm{X}_{1}$ & $\mathrm{X}_{2}$ & $X_{3}$ & $\mathrm{X}_{4}$ & $\mathrm{X}_{5}$ & $\begin{array}{l}Z \\
\text { score }\end{array}$ \\
\hline 2011 & 7.11 & 8.27 & 1.75 & 1.18 & 2.40 & 0.61 & 21.32 & -0.05 & 0.43 & 0.85 & 0.05 & 0.17 & -1.21 \\
\hline 2012 & 9.71 & 8.41 & 2.23 & 1.48 & 3.30 & 0.97 & 26.11 & -0.06 & 0.75 & 1.19 & 0.05 & 0.08 & -1.96 \\
\hline 2013 & 9.87 & 8.39 & 2.27 & 1.08 & 3.42 & 0.95 & 25.98 & -0.05 & 0.79 & 1.22 & 0.04 & 0.17 & -1.93 \\
\hline 2014 & 9.51 & 8.44 & 2.18 & 0.62 & 3.17 & 1.00 & 24.90 & -0.02 & 0.70 & 1.14 & 0.03 & 0.19 & -1.71 \\
\hline
\end{tabular}

Source: Authors

According to the above table, it can be asserted that the results for Ashur International Bank from Sherrod Z-score model for the year 2011 and 2014 were 21.32 and 24.90 respectively, this indicate that the results located within the second category which is a little likelihood of exposure to the risk of bankruptcy.
While in 2012 and 2013 were 26.11 and 25.98, this indicates that the financial position of Ashur International Bank is strong and it has a very good chance to continue with a degree of low risk when the Z-score increases. However, according to the outcomes of Kida's Z-score model for all the years the figures were negative, 
this indicate that Ashur International Bank may not be able to continue due to a potential serious problems which have a Z-score of negative.

\section{Babylon bank:}

Table (6): The outcomes of Sherrod and Kida models

\begin{tabular}{|c|c|c|c|c|c|c|c|c|c|c|c|c|c|}
\hline \multirow{2}{*}{$\begin{array}{l}\text { modey } \\
\text { years }\end{array}$} & \multicolumn{7}{|c|}{ Sherrod Model } & \multicolumn{6}{|c|}{ Kida Model } \\
\hline & $\mathrm{X} 1$ & $\mathrm{X} 2$ & $\mathrm{X} 3$ & $\mathrm{X} 4$ & $\mathrm{X} 5$ & X6 & Z-score & $\mathrm{X} 1$ & $\mathrm{X} 2$ & $\mathrm{X} 3$ & $\mathrm{X} 4$ & $\mathrm{X} 5$ & Z score \\
\hline 2011 & 5.05 & 8.11 & 1.39 & 0.43 & 1.99 & 0.40 & 17.36 & -0.02 & 0.28 & 0.69 & 0.03 & 0.15 & -0.87 \\
\hline 2012 & 4.51 & 8.13 & 1.29 & 0.39 & 1.90 & 0.38 & 16.60 & -0.02 & 0.25 & 0.66 & 0.03 & 0.19 & -0.76 \\
\hline 2013 & 6.18 & 7.86 & 1.72 & 0.30 & 2.35 & 0.39 & 18.79 & -0.01 & 0.41 & 0.79 & 0.03 & 0.07 & -1.17 \\
\hline 2014 & 6.54 & 6.98 & 2.13 & 0.37 & 3.07 & 0.27 & 19.37 & -0.02 & 0.67 & 0.92 & 0.03 & 0.05 & -1.58 \\
\hline
\end{tabular}

Source: Authors

Table (6) shows that the financial position of Babylon bank for the all years is very difficult to predict in terms of business failure based on Sherrod's Z-score model. The results located within the third category according to the degree

\section{Bank of Baghdad:}

Table (7): The outcomes of Sherrod and Kida models

\begin{tabular}{|c|c|c|c|c|c|c|c|c|c|c|c|c|c|}
\hline mode & Sher & Model & & & & & & Kida & & & & & \\
\hline & $\mathrm{X} 1$ & $\mathrm{X} 2$ & X3 & $\mathrm{X} 4$ & X5 & X6 & $\begin{array}{l}\text { Z- } \\
\text { score }\end{array}$ & $\mathrm{X} 1$ & $\mathrm{X} 2$ & $\mathrm{X} 3$ & $\mathrm{X} 4$ & X5 & $\begin{array}{l}\mathrm{Z} \\
\text { score }\end{array}$ \\
\hline 2011 & 2.05 & 8.65 & 0.56 & 0.57 & 1.43 & 0.41 & 13.67 & -0.02 & 0.08 & 0.53 & 0.03 & 0.14 & -0.52 \\
\hline 2012 & 2.14 & 8.70 & 0.56 & 0.46 & 1.43 & 0.48 & 13.76 & -0.02 & 0.08 & 0.53 & 0.02 & 0.17 & -0.48 \\
\hline 2013 & 2.26 & 8.71 & 0.58 & 0.44 & 1.44 & 0.51 & 13.94 & -0.02 & 0.08 & 0.53 & 0.02 & 0.16 & -0.50 \\
\hline 2014 & 2.19 & 8.72 & 0.56 & 0.36 & 1.43 & 0.51 & 13.76 & -0.02 & 0.08 & 0.53 & 0.02 & 0.15 & -0.50 \\
\hline
\end{tabular}

\section{Source: Authors}

From the table above we can see that Bank of Baghdad is exposed to the risk of bankruptcy based on Kida's Z-score during the study period and it has a weak financial position, as a negative $\mathrm{Z}$-score implies a problem in the bank.

of risk because the Z-score is less than 20 and bigger than 5 . On the other hand, based on the outcomes of Kida's Z-score, the results indicate that the probability of failure is high as the outcomes are negative.

\section{Commercial bank of Iraq:}

Table (8): The outcomes of Sherrod and Kida models

\begin{tabular}{|c|c|c|c|c|c|c|c|c|c|c|c|c|c|}
\hline $\bmod$ & Sherro & Mode & & & & & & Kida & odel & & & & \\
\hline & $\mathrm{X} 1$ & $\mathrm{X} 2$ & X3 & $\mathrm{X} 4$ & X5 & X6 & $\begin{array}{l}\text { Z- } \\
\text { score }\end{array}$ & X1 & $\mathrm{X} 2$ & X3 & $\mathrm{X} 4$ & X5 & $\begin{array}{l}\mathrm{Z} \\
\text { score } \\
\end{array}$ \\
\hline 2011 & 9.18 & 8.94 & 1.91 & 0.64 & 2.65 & 8.72 & 32.05 & -0.03 & 0.51 & 1.01 & 0.03 & 0.12 & -1.46 \\
\hline 2012 & 8.19 & 8.94 & 1.71 & 0.98 & 2.34 & 7.94 & 30.10 & -0.05 & 0.41 & 0.89 & 0.03 & 0.13 & -1.25 \\
\hline 2013 & 9.90 & 8.96 & 2.05 & 0.64 & 2.91 & 12.30 & 36.76 & -0.03 & 0.61 & 1.11 & 0.03 & 0.16 & -1.62 \\
\hline 2014 & 10.71 & 8.97 & 2.22 & 0.47 & 3.27 & 19.95 & 45.58 & -0.02 & 0.74 & 1.25 & 0.02 & 0.08 & -1.95 \\
\hline
\end{tabular}

\section{Source: Authors}

According to the outcomes of Kida's Z-score model it is obvious the $\mathrm{Z}$ score takes a negative slope during the period of study which reflects that the tendency of the company will have
Whereas, according to Sherrod's Z-score it is tricky to predict whether the bank faces the risk of bankruptcy during the study period as the Zscore is in the third category. 
was bigger than 25, it means Commercial bank of Iraq is not exposed to the risk of bankruptcy because it located within the first category of the model. Thus, it has a very good chance to continue with a degree of low risk.

\section{Credit bank of Iraq:}

Table (9): The outcomes of Sherrod and Kida models

\begin{tabular}{|c|c|c|c|c|c|c|c|c|c|c|c|c|c|}
\hline mode & \multicolumn{7}{|c|}{ Sherrod Model } & \multicolumn{6}{|c|}{ Kida Model } \\
\hline & $\mathrm{X} 1$ & $\mathrm{X} 2$ & $\mathrm{X} 3$ & $\mathrm{X} 4$ & $\mathrm{X} 5$ & X6 & $\begin{array}{l}\text { Z- } \\
\text { score }\end{array}$ & $\mathrm{X} 1$ & $\mathrm{X} 2$ & X3 & $\mathrm{X} 4$ & X5 & $\begin{array}{l}\mathrm{Z} \\
\text { score }\end{array}$ \\
\hline 2011 & 5.77 & 8.98 & 1.20 & 0.83 & 1.82 & 12.69 & 31.30 & -0.04 & 0.22 & 0.70 & 0.04 & 0.12 & -0.88 \\
\hline 2012 & 5.23 & 8.95 & 1.09 & 0.90 & 1.75 & 6.06 & 23.98 & -0.04 & 0.19 & 0.67 & 0.03 & 0.09 & -0.84 \\
\hline 2013 & 5.47 & 8.96 & 1.14 & 0.46 & 1.78 & 6.78 & 24.59 & -0.02 & 0.21 & 0.68 & 0.02 & 0.09 & -0.84 \\
\hline 2014 & 7.81 & 8.96 & 1.62 & 0.51 & 2.24 & 10.13 & 31.27 & -0.02 & 0.37 & 0.86 & 0.02 & 0.09 & -1.18 \\
\hline
\end{tabular}

Source: Authors

The results presented in table (9) shows that, with regards to Sherrod Z-score model, the $\mathrm{Z}$ value during the period of study we can observe a slight improvement in the financial performance of the bank where the $\mathrm{Z}$ value goes upwards and locate within the first and second category. Despite that, the $\mathrm{Z}$ value from 2011 to 2014 goes negatively, which means the Credit bank of Iraq will go through financial failure and a position of insolvency.

\section{Dar Es salam investment bank:}

Table (10): The outcomes of Sherrod and Kida models

\begin{tabular}{llllllll|lllllll}
\hline model & \multicolumn{1}{l}{ Sherrod Model } & \multicolumn{1}{l|}{ Kida Model } & & & & & \\
years & X1 & X2 & X3 & X4 & X5 & X6 & $\begin{array}{l}\text { Z- } \\
\text { score }\end{array}$ & X1 & X2 & X3 & X4 & X5 & $\begin{array}{l}\text { Z } \\
\text { score }\end{array}$ \\
\hline 2011 & 2.22 & 8.92 & 0.49 & 0.30 & 1.39 & 1.62 & 14.94 & -0.01 & 0.07 & 0.53 & 0.02 & 0.19 & -0.45 \\
\hline 2012 & 2.94 & 8.91 & 0.64 & 0.55 & 1.47 & 1.83 & 16.34 & -0.02 & 0.10 & 0.56 & 0.03 & 0.20 & -0.51 \\
\hline 2013 & 3.88 & 8.93 & 0.82 & 0.54 & 1.57 & 3.24 & 18.98 & -0.02 & 0.13 & 0.60 & 0.02 & 0.20 & -0.58 \\
\hline 2014 & 4.40 & 8.77 & 1.00 & 0.43 & 1.68 & 1.09 & 17.36 & -0.02 & 0.17 & 0.63 & 0.02 & 0.18 & -0.65 \\
\hline
\end{tabular}

\section{Source: Authors}

The results of Sherrod's Z-score model in table (10) indicate that the prediction of bankruptcy of the bank is difficult during the study period. Although there was a fluctuation in the Z-score out comes, it remained in the third category of the risk degree. The outcomes of Kida's Z-score, however, suggest that the bank may not be able to continue due to the risk of failure as the outcomes are negative.

\section{Gulf commercial bank:}

Table (11): The outcomes of Sherrod and Kida models

\begin{tabular}{|c|c|c|c|c|c|c|c|c|c|c|c|c|c|}
\hline model/ & \multicolumn{7}{|c|}{ Sherrod Model } & \multicolumn{6}{|c|}{ Kida Model } \\
\hline & $\mathrm{X} 1$ & $\mathrm{X} 2$ & $\mathrm{X} 3$ & $\mathrm{X} 4$ & $\mathrm{X} 5$ & X6 & $\begin{array}{l}\text { Z- } \\
\text { score }\end{array}$ & $\mathrm{X} 1$ & $\mathrm{X} 2$ & $\mathrm{X} 3$ & $\mathrm{X} 4$ & $\mathrm{X} 5$ & $\begin{array}{l}Z \\
\text { score }\end{array}$ \\
\hline 2011 & 4.40 & 8.47 & 1.20 & 0.73 & 1.76 & 0.59 & 17.15 & -0.04 & 0.22 & 0.64 & 0.04 & 0.08 & -0.85 \\
\hline 2012 & 5.09 & 8.51 & 1.23 & 1.71 & 1.86 & 0.64 & 19.04 & -0.08 & 0.23 & 0.67 & 0.06 & 0.10 & -0.94 \\
\hline 2013 & 5.73 & 8.52 & 1.36 & 1.43 & 1.96 & 0.73 & 19.74 & -0.06 & 0.27 & 0.71 & 0.05 & 0.13 & -0.97 \\
\hline 2014 & 6.14 & 8.42 & 1.48 & 1.05 & 2.08 & 0.66 & 19.84 & -0.05 & 0.31 & 0.75 & 0.05 & 0.12 & -1.03 \\
\hline
\end{tabular}

Source: Authors 
Results from table (11) shows that all the figures regarding to Sherrod's Z-score model are located within the third category $(20 \geq Z>5)$. In spite of the slightly risen in the figures still the probability of being insolvency is difficult.
However, according to the outcomes of Kida's $\mathrm{Z}$-score model for all the years the figures are negative, this indicates that Gulf commercial bank may not be able to continue and there is a high probability of bankruptcy.

\section{Investment bank of Iraq:}

Table (12): The outcomes of Sherrod and Kida models

\begin{tabular}{llllllll|lllllll}
\hline $\begin{array}{l}\text { model } \\
\text { years }\end{array}$ & Sherrod Model & \multicolumn{1}{l|}{ X1 } & X2 & X3 & X4 & X5 & X6 & $\begin{array}{l}\text { Z- } \\
\text { score }\end{array}$ & X1 & X2 & X3 & X4 & X5 & $\begin{array}{l}\text { Z } \\
\text { score }\end{array}$ \\
\hline 2011 & 5.37 & 8.63 & 1.25 & 0.04 & 1.87 & 0.86 & 18.02 & -0.03 & 0.24 & 0.69 & 0.03 & 0.13 & -0.86 \\
\hline 2012 & 4.60 & 8.63 & 1.09 & 0.18 & 1.74 & 0.76 & 17.01 & -0.01 & 0.19 & 0.64 & 0.03 & 0.11 & -0.76 \\
\hline 2013 & 5.75 & 8.74 & 1.25 & 1.21 & 1.90 & 1.23 & 20.08 & -0.05 & 0.24 & 0.71 & 0.04 & 0.12 & -0.93 \\
\hline 2014 & 8.29 & 8.72 & 1.78 & 1.25 & 2.49 & 1.64 & 24.16 & -0.05 & 0.45 & 0.93 & 0.05 & 0.17 & -1.31 \\
\hline
\end{tabular}

\section{Source: Authors}

Table (12) shows the outcomes of Kida's Zscore model from 2011 to 2014 were negative, this indicates that the prospect of bankruptcy is too high and has a weak financial position which leads to the failure in the near future. Nevertheless, it is obvious that the outcomes for Investment bank of Iraq from Sherrod Z-score model for the year 2011 and 2012 were 18.02

\section{Iraqi middle east investment bank:}

and 17.01 respectively, this indicates the difficulty of predicting the risk of bankruptcy because it located within the third category. While in 2013 and 2014 were just within the second category at 20.08 and 24.16, this indicates that the financial position of Investment bank of Iraq is a little likelihood of exposure to the risk of bankruptcy.

Table (13): The outcomes of Sherrod and Kida models

\begin{tabular}{llllllll|lllllll}
\hline $\begin{array}{l}\text { model } \\
\text { years }\end{array}$ & S1 & X2 & X3 & X4 & X5 & X6 & $\begin{array}{l}\text { Z- } \\
\text { score }\end{array}$ & X1 & X2 & X3 & X4 & X5 & $\begin{array}{l}\text { Z } \\
\text { score }\end{array}$ \\
\hline 2011 & 1.82 & 8.10 & 0.72 & 0.65 & 1.51 & 0.21 & 13.01 & -0.03 & 0.11 & 0.52 & 0.03 & 0.15 & -0.55 \\
\hline 2012 & 2.40 & 8.21 & 0.80 & 0.70 & 1.56 & 0.26 & 13.92 & -0.03 & 0.13 & 0.55 & 0.03 & 0.15 & -0.58 \\
\hline 2013 & 2.53 & 7.98 & 0.92 & 0.63 & 1.63 & 0.23 & 13.92 & -0.03 & 0.15 & 0.55 & 0.03 & 0.15 & -0.62 \\
\hline 2014 & 5.31 & 7.76 & 1.57 & 0.13 & 2.18 & 0.33 & 17.28 & -0.01 & 0.35 & 0.72 & 0.02 & 0.14 & -0.96 \\
\hline
\end{tabular}

Source: Authors

The outcomes from the Sherrod's Z-score model as it can be seen from table (13), all the figures located within the third category $(20 \geq Z$ $>5$ ). It demonstrates that the financial position of Iraqi Middle East investment bank is very difficult to predict whether the firm will go through a business failure or remain in the safe zone. On the contrary, all the figures rated a negative $\mathrm{Z}$ score according to the outcomes of Kida's Z-score model, this indicates that the financial position of the firm is very high to be in the dangerous zone, as in a distress zone there is a high probability of bankruptcy.

\section{Mosul bank for finance and investment:}

Table (14): The outcomes of Sherrod and Kida models

\begin{tabular}{llllllll|lllllll}
\hline $\begin{array}{l}\text { model } \\
\text { years }\end{array}$ & Sherrod Model & & & & & & \multicolumn{3}{l}{ Kida Model } & & & \\
\hline 2011 & 5.49 & 8.74 & 1.21 & 0.97 & 1.85 & 1.20 & 19.46 & -0.04 & 0.23 & 0.69 & 0.04 & 0.13 & -0.87 \\
\hline 2012 & 7.89 & 8.89 & 1.65 & 0.81 & 2.29 & 3.80 & 25.33 & -0.04 & 0.38 & 0.87 & 0.03 & 0.12 & -1.20 \\
\hline 2013 & 7.93 & 8.90 & 1.63 & 1.62 & 2.30 & 4.08 & 26.45 & -0.07 & 0.38 & 0.87 & 0.05 & 0.15 & -1.22 \\
\hline 2014 & 13.16 & 9.03 & 2.70 & 0.13 & 5.25 & 4.40 & 34.66 & -0.01 & 1.44 & 2.02 & 0.02 & 0.07 & -3.41 \\
\hline
\end{tabular}

Source: Authors 
It can be seen from the data in table (14) that in 2011 the Z-score of Sherrod model was 19.46 which means that the prediction of bankruptcy of Mosul bank is difficult. It is not an obvious indicator to judge on the financial position of the bank as long as the Z-score located within the third category of the risk degree. However, the Z-score has increased dramatically from 2012 to

\section{National bank of Iraq:}

Table (15): The outcomes of Sherrod and Kida models

\begin{tabular}{|c|c|c|c|c|c|c|c|c|c|c|c|c|c|}
\hline $\bmod$ & \multicolumn{7}{|c|}{ Sherrod Model } & \multicolumn{6}{|c|}{ Kida Model } \\
\hline yea & $\mathrm{X} 1$ & $\mathrm{X} 2$ & $\mathrm{X} 3$ & $\mathrm{X} 4$ & $\mathrm{X} 5$ & X6 & $\begin{array}{l}\mathrm{Z} \text { - } \\
\text { score }\end{array}$ & $\mathrm{X} 1$ & $\mathrm{X} 2$ & $\mathrm{X} 3$ & $\mathrm{X} 4$ & $\mathrm{X} 5$ & $\begin{array}{l}\mathrm{Z} \\
\text { score }\end{array}$ \\
\hline 2011 & 9.34 & 8.81 & 2.00 & 0.31 & 2.80 & 2.64 & 25.90 & -0.01 & 0.57 & 1.05 & 0.03 & 0.16 & -1.50 \\
\hline 2012 & 7.51 & 8.85 & 1.61 & 1.08 & 2.22 & 2.70 & 23.95 & -0.05 & 0.36 & 0.84 & 0.04 & 0.21 & -1.08 \\
\hline 2013 & 5.01 & 8.86 & 1.09 & 0.61 & 1.74 & 1.95 & 19.26 & -0.03 & 0.19 & 0.66 & 0.03 & 0.19 & -0.71 \\
\hline 2014 & 6.86 & 8.78 & 1.50 & 0.30 & 2.10 & 1.76 & 21.29 & -0.01 & 0.32 & 0.79 & 0.03 & 0.18 & -0.97 \\
\hline
\end{tabular}

Source: Authors

Above table shows the outcomes for National bank of Iraq from Sherrod Z-score model for the year 2013 was 19.26, this indicates that the score located in the third category, though it's difficult to predict the risk of bankruptcy. While in 2012 and 2014 were 23.95 and 21.29 , this means that the financial position of National bank of Iraq is a Little likelihood of exposure to the risk of bankruptcy. In 2011 the score was bigger than

\section{North bank for finance and investment:}

25 , it means that National bank of Iraq is not exposed to the risk of bankruptcy. Thus, it has a very good chance to continue while $Z$ value goes positively. With regards to Kida Z-score model the outcomes were disappointing because all the score were negative, this indicate that National bank of Iraq may not be able to continue and will go through financial failure and a position of bankruptcy.

Table (16): The outcomes of Sherrod and Kida models

\begin{tabular}{llllllll|llllll}
\hline model & \multicolumn{1}{l}{ Sherrod Model } & & & & & & \multicolumn{2}{l|}{ Kida Model } & & & & \\
\cline { 2 - 14 } years & X1 & X2 & X3 & X4 & X5 & X6 & $\begin{array}{l}\text { Z- } \\
\text { score }\end{array}$ & X1 & X2 & X3 & X4 & X5 & $\begin{array}{l}\text { Z } \\
\text { score }\end{array}$ \\
\hline 2011 & 9.34 & 8.81 & 2.00 & 0.31 & 2.80 & 2.64 & 25.90 & -0.01 & 0.57 & 1.05 & 0.03 & 0.16 & -1.50 \\
\hline 2012 & 7.51 & 8.85 & 1.61 & 1.08 & 2.22 & 2.70 & 23.95 & -0.05 & 0.36 & 0.84 & 0.04 & 0.21 & -1.08 \\
\hline 2013 & 5.01 & 8.86 & 1.09 & 0.61 & 1.74 & 1.95 & 19.26 & -0.03 & 0.19 & 0.66 & 0.03 & 0.19 & -0.71 \\
\hline 2014 & 6.86 & 8.78 & 1.50 & 0.30 & 2.10 & 1.76 & 21.29 & -0.01 & 0.32 & 0.79 & 0.03 & 0.18 & -0.97 \\
\hline
\end{tabular}

\section{Source: Authors}

Table (16) presents the results obtained from Sherrod and Kida Models. With regard to Sherrod model, it is apparent from this table that the Z-score of North bank from 2011- 2013 was 13.17, 12 and 14.05 respectively. These figures are located within the third category which means that the situation of the bank is difficult to predict the risk of bankruptcy. While in 2014 the

number has increased noticeably to achieve 28.36, which illustrates that the bank is not exposed to the risk of business failure. On the other hand, the results of Kida's Z-score model were negative for all years, which imply that there is a problem in this bank and it may experience the risk of bankruptcy in the near future.

\section{Sumer Commercial bank:}

Table (17): The outcomes of Sherrod and Kida models

\begin{tabular}{|c|c|c|c|c|c|c|c|c|c|c|c|c|c|}
\hline mode & \multicolumn{7}{|c|}{ Sherrod Model } & \multicolumn{6}{|c|}{ Kida Model } \\
\hline & $\mathrm{X} 1$ & $\mathrm{X} 2$ & X3 & $\mathrm{X} 4$ & X5 & X6 & $\begin{array}{l}\text { Z- } \\
\text { score }\end{array}$ & $\mathrm{X} 1$ & $\mathrm{X} 2$ & X3 & $\mathrm{X} 4$ & X5 & $\begin{array}{l}\mathrm{Z} \\
\text { score }\end{array}$ \\
\hline 2011 & 9.80 & 8.51 & 2.21 & 0.03 & 3.25 & 1.16 & 24.96 & -0.01 & 0.73 & 1.18 & 0.02 & 0.10 & -1.83 \\
\hline 2012 & 8.93 & 8.44 & 2.06 & 0.10 & 2.91 & 0.94 & 23.38 & -0.01 & 0.61 & 1.05 & 0.04 & 0.15 & -1.55 \\
\hline 2013 & 9.84 & 8.51 & 2.21 & 0.13 & 3.27 & 1.17 & 25.14 & -0.01 & 0.74 & 1.19 & 0.07 & 0.16 & -1.83 \\
\hline 2014 & 9.69 & 8.56 & 2.17 & 0.13 & 3.15 & 1.26 & 24.96 & -0.01 & 0.69 & 1.15 & 0.02 & 0.16 & -1.71 \\
\hline
\end{tabular}


Source: Authors

Table (17) presents different rating scores according to Sherrod's model. The Z-score of Sumer commercial bank in 2013 was 25.14 which mean that the financial position of the bank is strong and it has a very good chance to continue. While the outcomes of 2011, 2012 and 2014 were just under 25 which indicate that the 15. Union bank of Iraq:

Table (18): The outcomes of Sherrod and Kida models

\begin{tabular}{llllllll|lllllll}
\hline $\begin{array}{l}\text { model } \\
\text { years }\end{array}$ & Sherrod Model & X2 & X3 & X4 & X5 & X6 & $\begin{array}{l}\text { Z- } \\
\text { score }\end{array}$ & X1 & X2 & X3 & X4 & X5 & $\begin{array}{l}\text { Z } \\
\text { score }\end{array}$ \\
\hline 2011 & 6.61 & 8.49 & 1.56 & 0.63 & 2.16 & 0.79 & 20.25 & -0.03 & 0.34 & 0.78 & 0.03 & 0.16 & -1.03 \\
\hline 2012 & 3.02 & 8.83 & 0.69 & 0.72 & 1.49 & 1.06 & 15.81 & -0.03 & 0.10 & 0.56 & 0.03 & 0.16 & -0.57 \\
\hline 2013 & 6.81 & 8.68 & 1.53 & 2.14 & 2.13 & 1.24 & 22.53 & -0.09 & 0.33 & 0.79 & 0.10 & 0.11 & -1.20 \\
\hline 2014 & 6.08 & 8.73 & 1.36 & 0.53 & 1.96 & 1.29 & 19.95 & -0.02 & 0.27 & 0.73 & 0.06 & 0.12 & -0.96 \\
\hline
\end{tabular}

Source: Authors

Table (18) shows the outcomes for Union bank of Iraq from Sherrod Z-score model for the year 2012 and 2014 were 15.81 and 19.95 respectively, this indicates that the score located within the third category, though it is difficult to predict the risk of bankruptcy. While in 2011 and 2013 were 20.25 and 22.53, which has increased slightly, this means that the financial

\section{United bank for investment:}

Table (19): The outcomes of Sherrod and Kida models

\begin{tabular}{|c|c|c|c|c|c|c|c|c|c|c|c|c|c|}
\hline \multirow{2}{*}{ model } & \multicolumn{7}{|c|}{ Sherrod Model } & \multicolumn{6}{|c|}{ Kida Model } \\
\hline & $\mathrm{X} 1$ & $\mathrm{X} 2$ & $\mathrm{X} 3$ & $\mathrm{X} 4$ & $\mathrm{X} 5$ & X6 & $\begin{array}{l}\text { Z- } \\
\text { score }\end{array}$ & $\mathrm{X} 1$ & $\mathrm{X} 2$ & $\mathrm{X} 3$ & $\mathrm{X} 4$ & $\mathrm{X} 5$ & $\begin{array}{l}\mathrm{Z} \\
\text { score }\end{array}$ \\
\hline 2011 & 6.06 & 8.81 & 1.32 & 1.50 & 1.93 & 1.80 & 21.42 & -0.07 & 0.26 & 0.72 & 0.05 & 0.06 & -1.04 \\
\hline 2012 & 6.33 & 8.40 & 1.54 & 1.58 & 2.14 & 0.66 & 20.64 & -0.08 & 0.33 & 0.77 & 0.06 & 0.08 & -1.16 \\
\hline 2013 & 6.47 & 8.38 & 1.57 & 0.98 & 2.18 & 0.66 & 20.24 & -0.04 & 0.35 & 0.78 & 0.04 & 0.04 & -1.17 \\
\hline 2014 & 7.47 & 8.18 & 1.86 & 0.88 & 2.56 & 0.58 & 21.53 & -0.04 & 0.48 & 0.89 & 0.04 & 0.02 & -1.43 \\
\hline
\end{tabular}

Source: Authors

Table (19) illustrates that Sherrod's Z-score of United Bank from 2011 to 2014 were ( $25 \geq Z$ $>20$ ). In other words, as long as the Z-score is located within the second category of risk degree, there is a little likelihood of exposure to

position of Union bank of Iraq is strong and it has a very good chance to continue with a degree of low risk when the Z-score increases. Even so, according to the outcomes of Kida's Z-score model for all of the chosen years were negative, this means that the Union bank of Iraq will face a problems to keep business runs in the near future as the financial position seems to be weak.

Table (20): Comparative results of Sherrod and Kida models in terms of bankruptcy predictive ability

\begin{tabular}{llcc}
\hline \multicolumn{1}{c}{ Banks } & $\begin{array}{c}\text { Sherrod's Z-score } \\
\text { Mean }\end{array}$ & $\begin{array}{c}\text { Kida's Z-score } \\
\text { Mean }\end{array}$ \\
\hline 1 & Al-Mansour bank for investment & 22.41 & -1.148 \\
\hline 2 & Ashur International Bank & 24.58 & -1.70 \\
\hline 3 & Babylon bank & 18.03 & -1.09 \\
\hline 4 & Bank of Baghdad & 13.78 & -0.50 \\
\hline 5 & Commercial bank of Iraq & 36.12 & -1.57 \\
\hline 6 & Credit bank of Iraq & 27.79 & -0.94 \\
\hline 7 & Dar Es salam investment bank & 16.91 & -0.55 \\
\hline 8 & Gulf commercial bank & 18.94 & -0.95 \\
\hline 9 & Investment bank of Iraq & 19.82 & -0.96 \\
\hline 10 & Iraqi middle east investment bank & 14.53 & -0.68 \\
\hline
\end{tabular}




\begin{tabular}{llll}
\hline 11 & Mosul bank for finance and investment & 26.48 & -1.67 \\
\hline 12 & National bank of Iraq & 22.60 & -1.07 \\
\hline 13 & North bank for finance and investment & 16.90 & -2.11 \\
\hline 14 & Sumer Commercial bank & 24.61 & -1.73 \\
\hline 15 & Union bank of Iraq & 19.63 & -0.94 \\
\hline 16 & United bank for investment & 20.96 & -1.20 \\
\hline Total & 21.51 & -1.18 \\
\hline
\end{tabular}

Source: Authors

A comparison of the two results, as shown in table (20), reveals that the prediction of the majority of banks is difficult to predict based on Sherrod's Z-score model, as their ratings located within the third category of the risk degree. While the minority of banks are able to continue and they are not exposed to the risk of failure as their Z-score are more than 25. However, the ratings of the rest of banks indicate that their exposure to bankruptcy is very low as their Zscore is more than 20 and less than 25 . The interpretation, on the other hand, of Kida's Zscore illustrate that the financial position of all banks is weak and they will face potential serious problems in the near future. This is because the ratings of the banks are negative.

Overall, these results indicate that Sherrod's Z-score of the banks involved in this study located in the second category of the risk degree. This means that there is a little likelihood of exposure to the risk of bankruptcy. In contrast, the possibility of bankruptcy of the banks involved in the current study is very high based on Kida's Z-score. This is because the average rating of these banks is negative.

\section{Section Four: Conclusion and recommendations:}

1. Conclusion: The most obvious finding to emerge from this study is the followings:

1.1. The financial failure is considered a negative phenomenon which is experienced by firms. This is in turn may cause the firms to exit from the market.

1.2. There are a number of indicators or models which can be used by firms to predict the financial failure.

1.3. The accuracy of implementing business failure prediction models may give an early warning to firms before falling into the risk of bankruptcy.

1.4. The outcomes of Sherrod's Z-score revealed that the banks listed on (ISE) are successful, able to fulfil their obligations and far from the financial distress, although there is a very low probability that a few banks are exposed to the risk financial failure. While
Kida's Z-score model reported the opposite results for the same banks.

1.5. In addition, according to the latter model, the financial position of these banks is very weak and the probability of exposure to financial distress is relatively high. This is in contrast with the reality of these banks activities as their financial statements show that they are profitable, their liabilities are less than their assets and they are still working till now. The study has confirmed the findings of Ali (2014) which found that Kida's model could not give an actual picture about the financial position of firms. Hence, the present study provides additional evidence that Kida's model may not give accurate results about business failure prediction. As a consequence, this study has raised an important question about the accuracy of Kida's Z-score model.

\section{Recommendations:}

2.1 It is recommended that banks need to assess their financial position periodically to detect any financial distress problems so as to be remedied before getting worse.

2.2 It is recommended that banks can apply Sherrod's Z-score model for business failure prediction as it gives clear results about their future status.

2.3 The findings of the current study reveal that Bank can't take the advantage of Kida's Z-score model because its results did not coincide with actual reality.

2.4 This research has thrown up an important question about Kida's model in need of further investigation. Considerably more work will need to be done to determine the accuracy of Kida's model by taking failure firms with successful firms and this, in turn, may give a better picture about this model.

2.5 Further study could focus on another industry as a sample so as to examine the accuracy of these models as tools of business failure prediction.

\section{References:}


Abu Orabi, M.M. (2014). Empirical Tests on Financial Failure Prediction Models. Interdisciplinary journal of contemporary research in business, 5(9), 29-43.

Ahn, B. S., Cho, S. S., \& Kim, C. Y. (2000). The integrated methodology of rough set theory and artificial neural network for business failure prediction. Expert systems with applications, 18(2), 65-74.

Aktan, S. (2011). Early Warning System for Bankruptcy: Bankruptcy Prediction. (Doctoral thesis, des Karlsruher Instituts für Technologie (KIT), Germany). Retrieved 30 June 2016, from http://dnb.info/1019790032/34

Alhamdani, R. and Alqattan, Y. (2013). Using model Sherrod to measure the financial failure of a public company for the manufacture of medicines and medical supplies in Nineveh. Available at: http://www.iasj.net/iasj?func=fulltext $\&$ ald $=76478$ (access date June 12, 2016)

Ali, G. (2014). Contrast prediction models of financial failure in determining the financial position of companies. Available at: http://magazine.albaathuniv.edu.sy/magazine/pages/2014/2/1.pdf

(Accessed July 9, 2016).

Alkhatib, K., \& Al Bzour, A. E. (2011). Predicting corporate bankruptcy of Jordanian listed companies: Using Altman and Kida models. International Journal of Business and Management, 6(3), 208-215.

Arkan, Thomas (2015). Detecting financial distress with the Sherrod Model: a case Study. Finanse, Rynki Finansowe, Ubezpieczenia nr 74(2), 233-244.

Aziz, K. (2014). The role of business failure prediction and operating cash flows in banking stability. Available at: http://www.uokufa.edu.iq/journals/index.php/ghjec /article/view/3054/2561 (accessed June 15, 2016).

Boritz, J., Kennedy, D., \& Sun, J. (2007). Predicting business failures in Canada. Accounting Perspectives, 6(2), 141-165.

Edmister, R. O. (1972). An empirical test of financial ratio analysis for small business failure prediction. Journal of Financial and Quantitative analysis, 7(02), 1477-1493.

Fitzpatrick, P. (1932). A comparison of ratios of successful industrial enterprises with those of failed firms. Certified Public Accountant, 10-12, 598-605, 656-662, 727-731.

Gepp, A., \& Kumar, K. (2012). Business failure prediction using statistical techniques: A review. In K. Kumar \& A. Chaturvedi (Eds.). Some Recent Developments in Statistical Theory and Applications (pp 1-25). Boca Raton, Florida, USA: Brown Walker Press. Available at: http://epublications.bond.edu.au/cgi/viewcontent.c gi article $=1678 \&$ context $=$ business_pubs

Gharaibeh, M. A., Sartawi, I. M., Daradkah, D. (2013). The Applicability of Corporate Failure Models to Emerging Economies: Evidence from Jordan. Institute of Interdisciplinary Business Research, 4 (5), 313-325.

Gitman L. and Zutter C. (2012), Managerial Finance; 13th edition, Prentiss hall publishing.

Keener, M. H. (2013). Predicting the Financial Failure of Retail Companies in The United State. Journal of Business \& Economics Research, 11(8), 373-380.

Kida, T. (1980). An investigation into auditors' continuity and related qualification judgments. Journal of Accounting Research (Autumn): 506-523.

Mohammed, A. A. E. and Soon, N. K. (2012). Using Altman's Model and Current Ratio to Assess the Financial Status of Companies Quoted In the Malaysian Stock Exchange. International Journal of Scientific and Research Publications, 7(2), 1-11.

Okay, K. (2015). Predicting Business Failures Innon-Financial Turkish Companies. Retrieved 19 April 2016, from http://www.thesis.bilkent.edu.tr/0006970.pdf

Pike, R., \& Neale, B. (2009). Corporate finance and investment: Decisions \& strategies. 6th ed. Harlow, England: Financial Times/Prentice Hall.

Poston, K. M., Harmon, W. K., \& Gramlich, J. D. (1994). A test of financial ratios as predictors of turnaround versus failure among financially distressed firms. Journal of Applied Business Research, 10(1), 41.

Tatum, A., John. (2011). Predicting failure in the commercial banking industry - Munich Personal RePEc Archive. Mpra.ub.uni-muenchen.de. Retrieved 18 June 2016, from https://mpra.ub.unimuenchen.de/34608/

Uchenna, A.W. and Okelue, U. D. (2012). Predicting Corporate Business Failure in the Nigerian Manufacturing Industry. European Journal of Business and Management, 10(4), 86-93. 
كورتيا ليّكولينىّ:

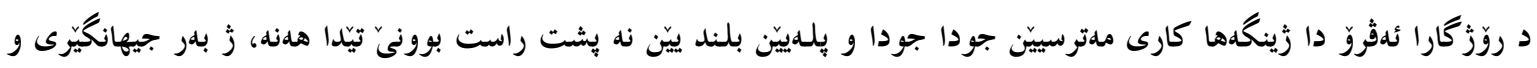

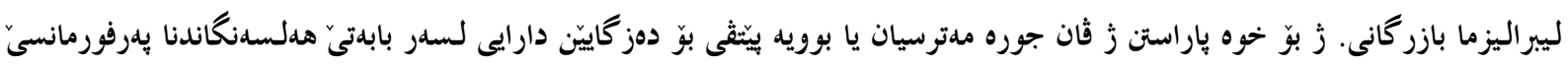

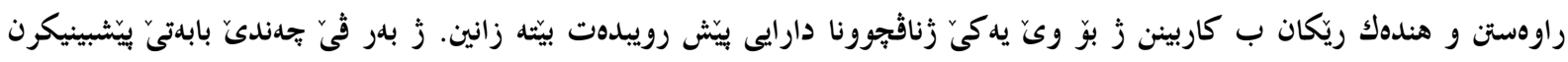

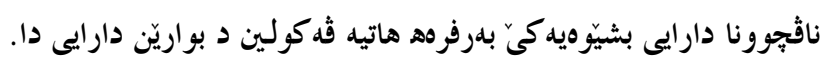

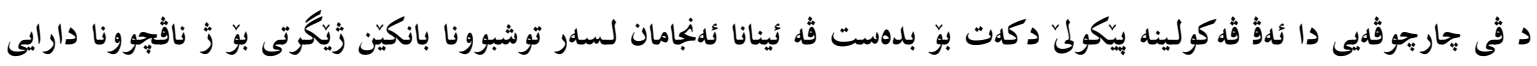

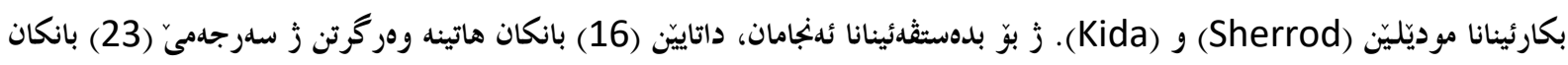

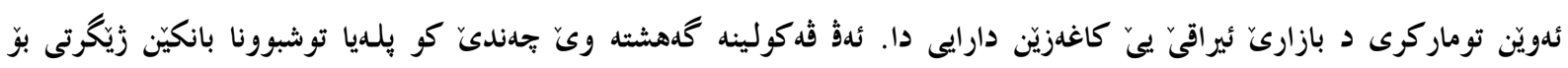

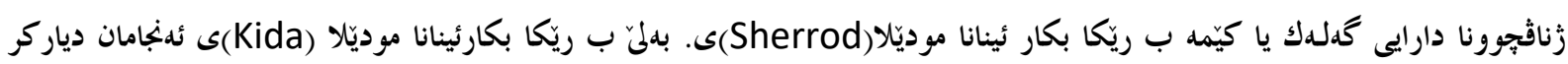

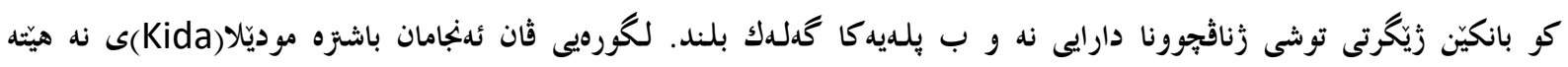

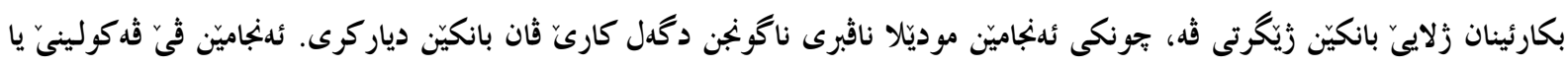

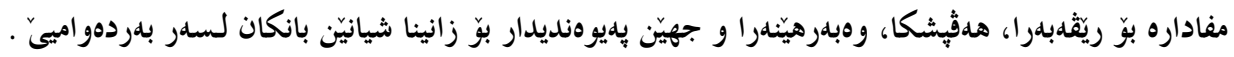

تتسم بيئة الأعمال في الوقت الحاضر بمخاطر متنوعة ودرجة عالية من اللاتأكد بسب العولمة و التحرر التجاري. ولتجنب هذه المخاطر اصبحت

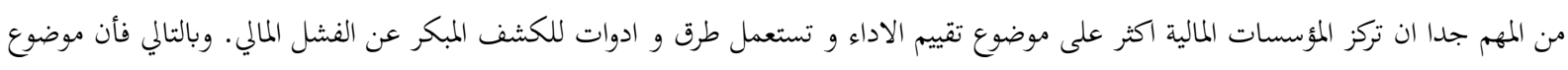

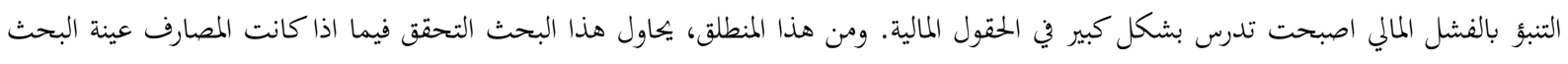

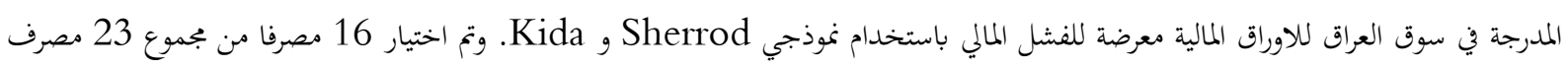

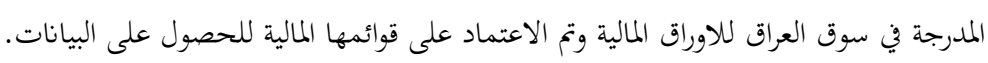

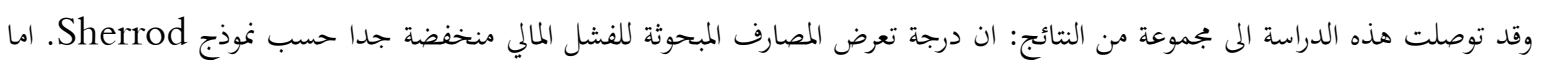

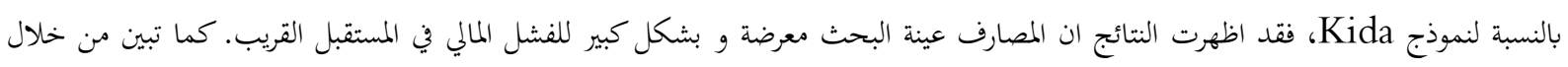

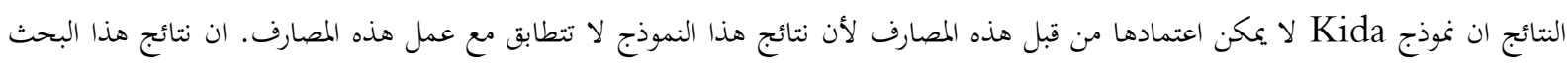

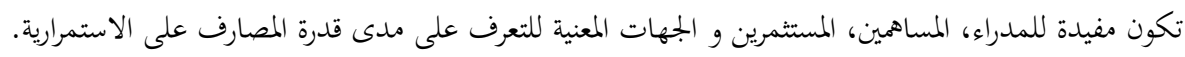

